\title{
A Study on Determinants of Participation in Rural Nonfarm Employment
}

\author{
S. Jagadees Pandi \\ Assistant Professor of Economics, Government Arts College (Autonomous), Karur, Tamil Nadu, India; \\ drsjpandi@gmail.com
}

\begin{abstract}
The present research has been conducted through field surveys in Rural Tamil Nadu to perceive the factors influencing the rural workers' participation in the nonfarm activities. A total of 240 workers comprising 143 wage employment and 97 self employment workers were taken in the study from the districts of Dindigul, Karur and Trichy. The nonfarm self employment workers were found to earn more than nonfarm wage employment workers. The empirical evidence from Multinomial result exposed that engaging in nonfarm employment was mostly by "push" factors, but less by "pull" factors at work. The result of Multinomial Logit Model also showed that there was difference in the effect of explanatory variables on participation of households in nonfarm wage and self employment activities. The explanatory variables such as age, educational status, community, family size did not emerge as significant factors. However the variables such as marital status, distance of travel, land holding, borrowing and livestock are the determinant factors of rural nonfarm (RNF) employment.
\end{abstract}

Keywords: Determinants, Multinomial Logit Model, Rural Nonfarm Employment (RNF), Self Employment, Wage Employment

\section{Introduction}

In a developing economy like India, man power is the prime wealth of the poor in rural areas. However, the growth of rural labour has outpaced agricultural labour impacting the agricultural sector to attract rural labour (Venkatesh 2013) ${ }^{1}$. In fact, the rural labour market has become a significant avenue for a source of living to a majority of households. Haggblade, Hazelland Reardon $(2010)^{2}$ observed that this sector alone accounted for 35 to 50 percent of rural incomes across the developing world.

Agriculture alone is not sufficient to mitigate poverty in the Central Asia dominated by population pressure, limited land resources, and incomplete agricultural reforms (World Bank, 200733 Maddock, 20094). Though, labour migration was once a common strategy resorted to for survival (ADB, 2008) $)^{5}$, the current economic scenario has posed uncertainty. In this backdrop, the rural nonfarm employment (RNFE) has emerged a notable source of earning to many.

The activities related to animal husbandry, fishing and hunting, forestry and logging are commonly included in nonfarm sector (Chadha 1993) ${ }^{6}$. Mining and quarrying, construction, trading, transport, storage, communication, hotels and community and personal services are the nonfarm activities. Generally, employmentin nonfarm activities enable earningjust enough to sustain subsistence (Reardon, 1997) 7 . Hence, identification of the factors leading to and earning from nonfarm activities is note worthy to refine rural policies (Reardon et al., 2006) ${ }^{8}$.

\section{Objective}

The specific objective of the study is to understand the factors that determine the participation in nonfarm employment in rural areas.

${ }^{*}$ Author for correspondence 


\section{Methodology}

The present research has been conducted through field survey in rural Tamil nadu from the districts of Dindigul, Trichy and Karur. These three districts are adjacent districts located in the central part of Tamil nadu. Covering 2 blocks in each of these three districts with a sample of 60 rural workers $(3 \times 2 \times 60)$ resulted in a total of 360 workers, of which 240 workers (143 wage employment workers and 97 self employment workers) were only full-time nonfarm rural workers and hence were considered as sample respondents. The study was conducted in the year 2015-16.

\section{Socio-Economic Status of RNF Workers}

In this section an attempt is made to analyse the relationship between responses of two different variables of the study. The inter relationship of the socio-economic variables are age, education, gender and income of the study respondents. To test the validity of the data, Chi-square test is applied.

From Table 1 a clear difference can be noticed between educational status and income from RNF employment. The differences are found much higher in case of wage employment in which a vast majority of respondents who had poor educational background, were earning a monthly income in the range of Rs. 4000 to 6000 only, while the respondents with good educational background were earning some reasonably high income.

The Chi-square test analysis at $5 \%$ significance with 12 degrees of freedom resulted in the calculated value for wage employment as 160.12 and for self employment as 23.10 against the table value of 21.62. Hence the null hypothesis is rejected and can be concluded that there is a significant association between educational status and income from RNF employment.

A significant positive relationship between education and nonfarm income at both household and individual levels has been empirically asserted (Deiniger and Olinte, 20019 ; Reardon, $\left.1997^{10}\right)$. Coppard $(2001)^{11}$ revealed that the education levels of those employed in rural nonfarm activities were higher than those who were engaged in agriculture.

Table 2 examines whether there is any significant relationship between ageof the respondents and their monthly income from RNF employment. The table reveals that a significant proportion of respondents belonging to self employment related to RNF work were earning in the range of both Rs. 4000 to 6000 pm and Rs. 6000 to 8000 $\mathrm{pm}$. However, a noticeable proportion of workers of wage employment were earning only up to Rs. 4000 pm as compared to the self employment workers.

From the analysis, the respondents of nonfarm self employment seem to earn more than nonfarm wage

Table 1. Comparison between Educational Statusand Monthly Income of Respondents

$\boldsymbol{H}_{o}$ : There is no significant relationship between Educational Level of respondents and Income from Rural Nonfarm Employment.

\begin{tabular}{|c|c|c|c|c|c|c|}
\hline \multirow{2}{*}{\multicolumn{2}{|c|}{$\begin{array}{l}\text { Educational Qualification } \\
\text { Below } 4000\end{array}$}} & \multicolumn{4}{|c|}{ Monthly Income } & \multirow{3}{*}{$\begin{array}{l}\text { Total } \\
46(32.1)\end{array}$} \\
\hline & & \multirow{2}{*}{$\begin{array}{l}4001-6000 \\
24(45.3)\end{array}$} & \multirow{2}{*}{\begin{tabular}{|l|}
$6001-8000$ \\
$22(29.7)$ \\
\end{tabular}} & \multirow{2}{*}{\begin{tabular}{|l|} 
Above 8000 \\
-- \\
\end{tabular}} & \multirow[b]{2}{*}{--} & \\
\hline \multirow{6}{*}{ 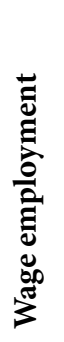 } & No formal education & & & & & \\
\hline & Primary level & $19(35.8)$ & $23(31.1)$ & -- & -- & $42(29.3)$ \\
\hline & Secondary level & $10(18.9)$ & $13(17.5)$ & $3(23.1)$ & -- & $26(18.1)$ \\
\hline & Higher secondary & -- & $14(18.9)$ & -- & $3(100)$ & $17(11.8)$ \\
\hline & Degree / diploma & -- & $2(2.7)$ & $10(76.9)$ & -- & $12(8.4)$ \\
\hline & Total & $53(100)$ & $74(100)$ & $13(100)$ & $3(100)$ & $143(100)$ \\
\hline \multirow{6}{*}{ 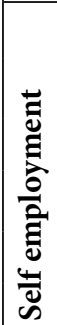 } & No formal education & $3(60.0)$ & $12(31.5)$ & -- & -- & $15(15.4)$ \\
\hline & Primary level & $2(40.0)$ & $6(15.7)$ & $3(8.3)$ & $7(38.9)$ & $18(18.5)$ \\
\hline & Secondary level & 0 & $11(28.9)$ & $12(33.3)$ & $5(27.8)$ & $28(28.9)$ \\
\hline & Higher secondary & 0 & $5(13.2)$ & $12(33.3)$ & $4(22.2)$ & $21(21.6)$ \\
\hline & Degree / diploma & 0 & $4(10.5)$ & $9(25.0)$ & $2(11.1)$ & $15(15.5)$ \\
\hline & Total & $5(100)$ & $38(100)$ & $36(100)$ & $18(100)$ & $97(100)$ \\
\hline
\end{tabular}

Source: Primary data Figs. in ( ) represent percentage of respondents 
Table 2. Comparison between Age and Monthly Income of Respondents

$\boldsymbol{H}_{\boldsymbol{o}}$ : There is no significant relationship between Age of respondents and Income from Rural Nonfarm Employment.

\begin{tabular}{|c|c|c|c|c|c|c|}
\hline \multirow{2}{*}{\multicolumn{2}{|c|}{$\begin{array}{l}\text { Age } \\
\text { Below } 4000\end{array}$}} & \multicolumn{4}{|c|}{ Monthly Income } & \multirow{3}{*}{$\begin{array}{l}\text { Total } \\
22(15.3)\end{array}$} \\
\hline & & \multirow{2}{*}{$\begin{array}{l}4000-6000 \\
6(11.3)\end{array}$} & \multirow{2}{*}{$\begin{array}{l}6000-8000 \\
16(21.6)\end{array}$} & \multirow{2}{*}{$\begin{array}{l}\text { Above } 8000 \\
--\end{array}$} & \multirow[b]{2}{*}{--} & \\
\hline \multirow{4}{*}{ 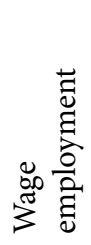 } & Below 30 & & & & & \\
\hline & $31-50$ & $38(71.7)$ & $36(48.6)$ & $7(53.8)$ & -- & $81(56.6)$ \\
\hline & Above 51 & $9(17.0)$ & $22(29.7)$ & $6(46.2)$ & $3(100)$ & $40(27.9)$ \\
\hline & Total & $53(100)$ & $74(100)$ & $13(100)$ & $3(100)$ & $143(100)$ \\
\hline \multirow{4}{*}{ 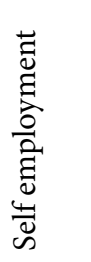 } & Below 30 & -- & $6(15.8)$ & $7(19.4)$ & -- & $13(13.4)$ \\
\hline & $31-50$ & $3(60.0)$ & $19(50.0)$ & $22(61.1)$ & $12(66.7)$ & $56(57.7)$ \\
\hline & Above 51 & $2(40.0)$ & $13(34.2)$ & $7(19.4)$ & $6(33.3)$ & $28(28.8)$ \\
\hline & Total & $5(100)$ & $38(100)$ & $36(100)$ & $18(100)$ & $97(100)$ \\
\hline
\end{tabular}

Source: Primary data Figs. in ( ) represent percentage of respondents

Table 3. Comparison between Gender and Reasons for taking up the RNF Employment

$H_{o}$ : There is no significant relationship between gender and the reasons for taking up the RNF work.

\begin{tabular}{|c|c|c|c|c|}
\hline \multirow{2}{*}{\multicolumn{2}{|c|}{$\begin{array}{l}\text { Reasons for taking up the RNF work } \\
\text { Male }\end{array}$}} & \multicolumn{2}{|l|}{ Gender } & \multirow{3}{*}{$\begin{array}{l}\text { Total } \\
17(11.8)\end{array}$} \\
\hline & & \multirow{2}{*}{$\frac{\text { Female }}{17(14.7)}$} & \multirow[b]{2}{*}{--} & \\
\hline \multirow{6}{*}{ 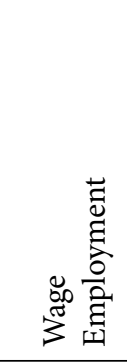 } & Comparatively lucrative wage rate / income & & & \\
\hline & Lack of alternative employment & $30(25.8)$ & $6(22.2)$ & $36(25.1)$ \\
\hline & Jobs availed nearby the residential place & $51(44.0)$ & $21(77.8)$ & $72(50.3)$ \\
\hline & Additional benefits & $10(8.6)$ & -- & $10(7.0)$ \\
\hline & No harsh work & $8(6.8)$ & -- & $8(5.6)$ \\
\hline & Total & $116(100)$ & $27(100)$ & $143(100)$ \\
\hline \multirow{6}{*}{ 䟫 } & Comparatively lucrative wage rate / income & $22(26.9)$ & $3(20.0)$ & $25(25.7)$ \\
\hline & Lack of alternative employment & $12(14.6)$ & -- & $12(12.3)$ \\
\hline & $\begin{array}{l}\text { Jobs availed nearby the residential place/home } \\
\text { based work }\end{array}$ & $37(45.1)$ & $12(80.0)$ & $49(50.5)$ \\
\hline & Additional benefits & $11(13.4)$ & -- & $11(11.3)$ \\
\hline & No harsh work & -- & -- & -- \\
\hline & Total & $82(100)$ & $15(100)$ & $97(100)$ \\
\hline
\end{tabular}

Source: Primary data Figs. in ( ) represent percentage of respondents

employment. However, research studies indicated that the share of nonfarm wage employment in the total nonfarm income was higher (Berdegue et al., 2001 ${ }^{12}$; Ruben and Van den berg $2001^{13}$; Isgut $\left.2004^{14}\right)$. In India, Lanjouw and Shariff $(2004)^{15}$ examined that RNF wage income was more important than self employment income to both average household and the poorest. Contrarily, the main reason attributed more for self employment income in the present study is that, a vast majority of workers in wage employ- ment were doing casual work in which income earned was neither regular nor highly remunerative. Hence self employment yields reasonably good income than wage employment.

The Chi square test analysis at 5\% significance with 6 degrees of freedom resulted in the calculated value for wage employment as 12.48 and for selfemploymentas 6.54 against the table value of 12.60 . Hence the null hypothesis is accepted and can be concluded that there is no significant 
association between age and income from RNF employment. The relationship of age and income were already discussed in few research studies. Maja $(2007)^{16}$ established that there is a significant relationship between age and income from RNF employment in Eastern Himalayas. The result of the present study is not surprising given that, working as an unskilled labourer is mostly a strenuous activity for which the reward is not high. Also the return from low investment self employment RNF work is low only and hence this is the possible reason for insignificant relationship between age of the respondents and their income from RNF employment in the present study.

Table 3 discloses that in case of wage employment, a majority of male respondents chose to RNF work because either it was available nearby their area or for the reason of lack of alternative employment nearby. A maximum of male workers of self employment had preferred the RNF work since the location of the work was either close to their residence or at their own house. Besides, one-third had opted the RNF work for earning better income as it was comparatively lucrative. As far as female respondents were concerned, a majority of them in both wage and self employment categories cited the reason of nearby place of employment/home based work, which clearly explains that the female in rural area preferred to work only in the nearby places of their residential area as they have additional responsibilities in household chores.

Table 4. Determination of Participation in Rural Nonfarm Employment: Result of Multinomial Logit Model

\begin{tabular}{|c|c|c|c|c|}
\hline \multirow[t]{3}{*}{ Parameter Estimates } & \multicolumn{4}{|c|}{ Choice of Employment } \\
\hline & \multicolumn{2}{|c|}{$\begin{array}{l}\text { Wage Employment } \\
\text { Ref: Self Employment }\end{array}$} & \multicolumn{2}{|c|}{$\begin{array}{l}\text { Self Employment } \\
\text { Ref: Wage Employment }\end{array}$} \\
\hline & Co-efficient & Std. Error & $\begin{array}{l}\text { Co- } \\
\text { efficient }\end{array}$ & Std. Error \\
\hline Intercept & -13.027 & 1.309 & 13.027 & 1.309 \\
\hline Age & .093 & .052 & -.093 & .052 \\
\hline Acres of irrigated land & -3.442 & $1.330^{*}$ & 3.442 & $1.330^{\star}$ \\
\hline Acres of unirrigated land & -8.318 & $1.972^{\star *}$ & 8.318 & $1.972^{\star *}$ \\
\hline Family size & -.612 & .398 & .612 & .398 \\
\hline [Gender=Male $]$ & -.789 & 1.269 & .789 & 1.269 \\
\hline$[$ Community $=\mathrm{SC} / \mathrm{ST}]$ & -.093 & 1.117 & .093 & 1.117 \\
\hline$[$ Community $=\mathrm{BC}]$ & -1.436 & 1.155 & 1.436 & 1.155 \\
\hline [Marital status =Single] & -1.748 & 2.109 & 1.748 & 2.109 \\
\hline [Marital status = Married $]$ & 4.587 & $1.808^{\star}$ & -4.587 & $1.808^{\star}$ \\
\hline $\begin{array}{l}\text { [Distance of work }=\text { Within } 5 \mathrm{Km} \\
\text { radius] }\end{array}$ & 11.701 & $1.562^{\star *}$ & -11.701 & $1.562^{* *}$ \\
\hline $\begin{array}{l}\text { [Distance of work }=6 \text { to } 10 \mathrm{Km} \\
\text { radius] }\end{array}$ & 9.843 & $1.545^{\star *}$ & -9.843 & $1.545^{\star *}$ \\
\hline $\begin{array}{l}\text { [Edu. Qualification= No formal } \\
\text { education] }\end{array}$ & 4.824 & 2.471 & -4.824 & 2.471 \\
\hline $\begin{array}{l}\text { [Edu. Qualification = Primary } \\
\text { level }]\end{array}$ & -.611 & 2.368 & .611 & 2.368 \\
\hline $\begin{array}{l}\text { [Edu. Qualification = Secondary } \\
\text { level] }\end{array}$ & 3.066 & 2.363 & -3.066 & 2.363 \\
\hline $\begin{array}{l}\text { [Edu. Qualification = Higher } \\
\text { secondary] }\end{array}$ & -.810 & 2.370 & .810 & 2.370 \\
\hline Credit & .001 & $.000^{* *}$ & -.001 & $.000^{\star *}$ \\
\hline Live stock & 5.427 & $1.707^{\star}$ & -5.427 & $1.707^{\star}$ \\
\hline
\end{tabular}

Note : ${ }^{* *}$ and ${ }^{*}$ indicate statistical significance at 1 and $5 \%$ probabilitylevels, respectively. Dependent variable: Participation. Number of observations: 240 
The Chi-square test analysis at 5\% significance with 4 degrees of freedom resulted in the calculated value for wage employment as 8.79 and for self employment as 10.16 against the table value of 9.49 . Hence the hypothesis is acceptedin case of wage employment and can be concluded that there is no significant relationship between gender andthe reasons for taking up RNF wage employment, while there is a significant association between gender andthe reasons for taking up RNF self employment.

\section{Determinants of Rural Non Farm Employment (RNFE)}

Examining the determinants of participation in RNFE activities by the rural households is important for better understanding of the phenomenon in order to draw some meaningful policy inferences. These determinants are therefore estimated by using Multinomial Logistic Regression Model (Schwab, J. A. 2002) ${ }^{17}$ in respect of the respondents participating in RNFE. Separate analysis for participation in nonfarm wage employment and nonfarm self employment were made. The coefficients from the multinomial logit (MNL) estimates present the findings pertaining to the factors that affect the likelihood of participation in nonfarm wage employment and nonfarm self employment activities.

In terms of Tassew and Oskam $(2001)^{18}$, the multinomial logit model can be detailed as below:

Let mark the utility that the household gets from choosing alternative activity $j$, then

$$
U_{i j t}=\beta_{j} X_{i t}+v_{i j t}
$$

Where xjt indicates a vector of coefficients specific to state $j$, and $X$ denotes individual characteristics, vijt $j$ is a random error term.

The present study uses MNL model in which individuals are sorted into two labour force categories viz., wage employed workers and self employed workers. Hence, $Y_{i}=$ 1 if an individual is employed in wage employment; $Y_{i}=2$ if an individual is employed in self employment; $\mathrm{X}_{i}$ represents a specific explanatory variable.

Further, $P_{i j}=j(1,2)$ which mark the probability associated with thenonfarm activity choices of household $i$ with $j$ $=1$, if thehousehold participates in nonfarm wage employment, $\mathrm{j}=2$, if the household engages in nonfarm self employment. The independent variables include personal and household attributes as well as the socio-economic background. Therefore, personal attributes in the present study are the age, level of education, marital status, household size etc.
The empirical evidence from multinomial result revealed in Table 4 explains that engaging in non farm activities is mainly due to "push" factors (inability to earn adequately from agricultural works), and less by "pull" factors (higher payoffs or lower risk in the nonfarm sector) (Atamanov 2011 ${ }^{19}$; Fox and Sohnesen, 2012 ${ }^{20}$; Paula Nagler, $\left.2011^{21}\right)$.

The results of multinomial logit model are as follows:

\subsection{Age}

The result of the present study indicates that age of the respondents is not a significant factor in determining the participation in RNF work. The possible explanation for this finding is that, RNF work is the only alternative avenue for rural folk. When they are highly deprived of the income from agriculture, choosing nonfarm work is inevitable, where age is not a barometer to engage. However research study by Launjow and Shariff $(2004)^{22}$ confirmed that younger the age, the probability of involving in the agriculturalwork was higher, but with aging the probability of involving in RNF workwas higher.

\subsection{Gender}

Research studies confirmed that gender is an important determinant of accepting RNF works.In Madhya Pradesh and Orissa, many nonfarm activities are undertaken by women while, other jobs are taken by men (Pandey, 200223; Somet al, $\left.2002^{24}\right)$. Average female participation rates in the nonfarm activities are lower than those of men (Coppard, $2001)^{25}$.

The multinomial results of the present study explain thatgender is not an important factor determining participation in nonfarm wage and self employment. It can be interpreted that female respondents' intensity to work in RNF wage work and to take up low income business is equivalent to male respondents in regions with poor opportunities to work in farm sector.

\subsection{Education}

Generally, higher education ensures employment in public and private nonfarm organizations, while self employment nonfarm activities call for only vocational or secondary education.

As far as the present study is concerned, education is not a significant factor determining rural nonfarm wage and self employment. The possible reason is that, a vast majority of the study respondents are casual workers and low investment business entrepreneurs. Participation in 
these employments does not require good educational backgrounds.

\subsection{Community}

There is no statistically significant effect regarding employment in nonfarm labour in the present study. Invariably, the rural nonfarm employment be it for wage or as self employment with low income generation activities are carried out by people of all castes and it is not confined to any community.

\subsection{Family Size}

The result of the study explains that household size is positively and significantly related to wage employment but not to self employment. This implies that large households are more likely to be engaged in wage employment, but there is no similar propensity as far as self employment is concerned.

\subsection{Cultivation of Land}

Theoretically, there is an inverse relation between landholding size and the share of nonfarm income in the total household income. The result of the study shows that both irrigated and rain fed agriculture turn out to be negatively significant as far as the RNF wage employment is concerned, because higher the proportion of land holding, greater the propensity for cultivation of land and they can relocateto farming. However this case is not applicable for self employment.

Studies in Africa, contradicts by exposing a positive impact of land holding on being employed in nonfarm activities (Abdulai and CroleRees, 2001) ${ }^{26}$. Studies, in Latin America, affirms the present study by exhibiting that poor households largely accepted nonfarming due to land scarcity and excess of labour (Berdegue, J.A et al., 200127; Davis et al., 2007 ${ }^{28}$ ). On the other hand, studies by (Kharatyan, $2002^{29}$; Kobaladze, $2002^{30}$ ) reveal that land ownership is not at all a deciding factor for engaging in the RNF works.

Babatunde (2009) ${ }^{31}$ identified the causes of participating in nonfarm employment and concluded that the share of nonfarm income increases with farm size.

\subsection{Livestock}

Co-efficient shows that the size of livestock is significantly and positively correlated at 5 percent level with wage employment, which means that more the livestock holding, more is the income earned from nonfarm wage employment activities. The size of livestock also found to be important determinant of participation in high-return nonfarm activities as against low-return ones (Lay et. al., $2008)^{32}$.

\subsection{Credit}

A study by André Croppenstedt (2006) ${ }^{33}$ in rural Egypt shows that the availability of credit is positively correlated to the degree to which income is derived from wage employment, both at the household and individual level for male folks. This may be due to households holding salaried jobs having more access to credit or that households needed to engage in wage employment above what they normally would do in response to having taken up credit. However the present study explains that credit amount is significantly and negatively correlated with wage employment and is significantly and positively correlated with self employment. This may be due to households holding good business income having more access to credit. Moreover, as compared to wage employment, workers in self employment require more credit for the expansion or survival of firm, whereas wage employment workers require credit mainly for household maintenance. Hence increase the odds for loan amount, decrease the participation in wage employment and they can relocate alternative employment like on-farm employment in order to repay the credit amount.

\subsection{Travel Distance}

Infrastructure facilities do determine the participation in non farm activities. Thus, the travel distance to reach the work place significantly and positively affected the participation in nonfarm wage employment activities while; it is negatively related to self employment activities. The place of work is shorter to reach increases the likelihood to participate in wage employment. The rural workers particularly female do not want to go for long distances as they have to manage their household chores. This was the principal reason behind the larger participation of women in Public Works like MGNREGA, which are performed within the neighbourhood of the villages. However this case is not suitable for self employment works. Most of the study respondents in self employment carried out their business as home based work; distant to reach the work place was immaterial.

\section{Key Findings}

- Women participate more in unskilled wage employment and low investment business of the nonfarm sector.

- Majority of the nonfarm activities are survival oriented and have little to do with wealth accumulation. 
- The nonfarm sector is multifarious and hence equal access to varied segments of this sector is not available.

- When the determinants are compared across different types of nonfarm employment, taking up low return activities is largely influenced by push factors (low or insufficient income).

- Education is not a significant factor determining the participation in RNF employment, since majority of the respondents are doing low income business activities and unskilled casual employment, where education is not a passive factor to avail these activities.

- The result of MNL confirmed the difference in the effect of explanatory variables on deciding of the households to work in nonfarm wage and self employment activities. The explanatory variables such as age, educational status, community, family size did not emerge as significant factors. However the variables such as marital status, distance of travel, land holding, borrowing and livestock are the determinant factors for RNF employment.

\section{Suggestions}

- Application of appropriate policy programmes by the concerned authorities to serve both farm and nonfarm promotional purposes. Example: Developing accessible credit schemes to initiate nonfarm businesses and as well promote agricultural activities.

- Many challenges such as education, infrastructure etc., in rural India needs to be addressed at policy levels.

\section{Conclusion}

The study examined the different factors that influence the decision to take up nonfarm employment in rural Tamil nadu. Making a comparison of the nonfarm employment between wage employment and self employment, the study ensured testing of the factors influencing participation in these nonfarm activities. Based on the findings, it is concluded that the RNF sector which consists of casual wage and low investment self employment opportunities dominate the job market in the area of the study.

\section{References}

1. Venkatesh P. Recent Trends in Rural Employment and Wages in India: Has the Growth Benefitted the Agricultural Labours? Journal of Agricultural Economics and Research. 26 (Conference Number). 2013; 13-20.
2. Haggblade S, Hazell P, Reardon T. The Rural Nonfarm Economy: Prospects for Growth and Poverty Reduction. World Development. 2010; 38(10):1429-41. https://doi. org/10.1016/j.worlddev.2009.06.008.

3. World Bank. Agriculture for Development: world Development Report 2008: Washington DC, World Bank.

4. Maddock N. Note on actions in rural development in Central Asia, Central Asia Cluster Meeting: Almaty 3-5 December 2009.

5. Asian Development Bank. A Study on International Migrants' Remittances in Central Asia and South Caucasus. Country Report on Remittances of International Migrants in Tajikistan. 2008.

6. Chadha GK. Non-Farm Employment for Rural Households in India, Evidence and Prognosis. Indian Journal of Labour Economics. 1993; 36(3):296-327.

7. Reardon T. Using evidence of household income diversification to inform study on the rural non-farm labour market in Africa. World Development. 1997; 25(5):735-47. https://doi. org/10.1016/S0305-750X(96)00137-4

8. Reardon et al. Household Income Diversification into Rural Nonfarm Activities. Part II, Chapter 6. In: Haggblade S, Hazell P, Reardon T. Transforming the Rural Nonfarm Economy. Baltimore: The Johns Hopkins University Press. 2006; 115-40. PMid:16382120

9. Deiniger K, Olinte P. Rural nonfarm employment and income diversification in Colombia. World Development. 2001; 29(3): 455-65. https://doi.org/10.1016/S0305-750X(00)00106-6.

10. Reardon T. Using evidence of household income diversification to inform study on the rural non-farm labour market in Africa. World Development. 1997; 25(5):735-47. Crossref

11. Coppard D. The rural non-farm economy in India: A review of the literature. NRI Report No. 2662, Chatham: NRI, 2001.

12. Berdegue JA, Ramirez E, Reardon T, Escobar G. Rural Non-farm Employment and Incomes in Chile. World Development. 2001; 29(3):411-25. https://doi.org/10.1016/ S0305-750X(00)00102-9.

13. Ruben R, Van den berg M. Nonfarm Employment and Poverty Alleviation of Rural Farm Households in Honduras. World Development. 2001 Mar; 29(3):549-60. https://doi. org/10.1016/S0305-750X(00)00107-8.

14. Isgut AE. Non-Farm Income and Employment in Rural Honduras: Assessing the Role of Locational Factors. Journal of Development Studies. 2004 Feb; 40(3):59-86. https://doi. org/10.1080/0022038042000213201.

15. Lanjouw P, Shariff A. Rural Nonfarm Employment in India: Access, Income, and Poverty Impact. Working Paper Series no 81. New Delhi: National Council of Applied Economic Research, 2004.

16. Micevsa M, Bahadur D. Rural Non-farm employment and income in the eastern Himalayas. Center for Development Research, University of Bonn. 2007. 
17. Schwab JA. Multinomial logistic regression. Basic relationships and complete problems, 2002. Available from: http:// www. Utexas.edu./courses/Schwab/ solving problems

18. Tassew W, Oskam A. Income diversification and entry barriers: evidence from the Tigray Region of Northern Ethiopia. Food Policy. 2001; 26(4):351-65. https://doi.org/10.1016/ S0306-9192(01)00009-4.

19. Atamanov A, van den Berg M. Microeconomic analysis of rural nonfarm activities in the Kyrgyz Republic: What determines participation and returns? Working Paper series 2011WP001, Maastricht Graduate School of Governance, The Netherlands. 2011.

20. Louis F, Sohneson TP. Household Enterprises in Sub-Saharan Africa: Why they Matter for Growth, Jobs and Livelihoods. Policy Research Working Papers No.6184. Washington DC: World Bank. 2012.

21. Paula N. A Profile of nonfarm household enterprises in SubSaharan Africa, UNU-MERIT working paper 2017-048. 2017.

22. Lanjouw P, Shariff A. Rural Nonfarm Employment in India: Access, Income, and Poverty Impact. Working Paper Series no 81. New Delhi: National Council of Applied Economic Research. 2004.

23. Pandey R, Cannon T, Jena G, Wandschneider T. Rural nonfarm employment in Nayagarh District of Orissa: Findings from a participatory rural appraisal. Chatham: NRIReport No. 2694, Chatham: NRI. 2002.

24. Som R, Kleih U, Kumar Y, Jena SK. Rural non-farm employment in Madhya Pradesh: Findings of a participatory rural appraisal in 8 villages. NRI Report No. 2694, Chatham: NRI. 2002.

25. Coppard D. The rural non-farm economy in India: A review of the literature. NRI Report No. 2662, Chatham: NRI. 2001.

26. Abdulai A, Crolerees A. Determinants of income diversification amongst rural households in Southern Mali. Food Policy. 2001; 26:437-52. https://doi.org/10.1016/S03069192(01)00013-6.

27. Berdegue JA, Ramirez E, Reardon T, Escobar G. Rural Non-farm Employment and Incomes in Chile. World Development. 2001; 29(3):411-25. https://doi.org/10.1016/ S0305-750X(00)00102-9.
28. Davis B, Winters P, Carletto G, Covarrubias K, Qui-ones EJ, Zezza A, Stamoulis K, Azzarri C, Digiuseppe S. A Cross-Country Comparison of Rural Income Generating Activities. World Development. 2010; 38:48-63. https://doi. org/10.1016/j.worlddev.2009.01.003.

29. Kharatyan H. Development of non-farm activities in the Armenian village. NRI Report No. 2680, Chatham: NRI Report No. 2681, Chatham: NRI. 2002.

30. Kobaladze K. A study of non-farm activities in FSU Georgia: A regional focus. NRI Report No. 2681, Chatham: NRI. 2002.

31. Babatunde RO, Qaim M. Patterns of Income Diversification in Rural Nigeria: Determinants and Impacts. Quarterly Journal of International Agriculture. 2009; 48(4):305-20.

32. Lay J, Mahmoud TO, M'mukaria GM. Few Opportunities, Much Desperation: The Dichotomy of Non-Agricultural Activities and Inequality in Western Kenya. World Development. 2008; 36:2713-32. https://doi.org/10.1016/j. worlddev.2007.12.003.

33. Croppenstedt A. Household Income Structure and Determinants in Ryral Egypt. Working Paper 06-02, Agricultural Development Economic division of the Food and Agriculture Organisation of United Nations (FAO ESA). 2006.

34. Abdulai A, Delgado CL. Determinants of Nonfarm Earnings of Farm- based Husbands and Wives in Northern Ghana. American Journal of Agricultural Economics. 1999; 81:11730. https://doi.org/10.2307/1244455.

35. Bhalla and Hazell. Rural Employment and Poverty - Strategies to Eliminate Rural Poverty within a Generation. Economic and Political Weekly. 2003 Aug; 38(33):16-22

36. Bhaumik SK. Diversification of Employment and Earnings by Rural Households in West Bengal. Indian Journal of Agricultural Economics. 2007; 62(4):585-606.

37. Mishra AK, Goodwin BK. Farm income variability and the supply of farm Labor. American Journal of Agricultural Economics. 1997; 79:880-7. https://doi.org/10.2307/1244429.

38. Wandschneider T, Davis J. Rural non-farm employment in transition economies. Proceedings of a workshop held at the Old Royal Naval College. University of Greenwich, London. Chatham: NRI. 2002 6-7 Mar 